\title{
Host status of eucalypt species to Pratylenchus brachyurus and Meloidogyne incognita
}

\author{
Victor Hugo Moura de Souza 1,* (1) https://orcid.org/0000-0002-7576-4676 \\ Mário Massayuki Inomoto' (iD) https://orcid.org/0000-0001-9870-8194 \\ 1. Universidade de São Paulo - Escola Superior de Agricultura “Luiz de Queiroz” - Departamento de Fitopatologia e Nematologia - \\ Piracicaba (SP), Brazil. \\ *Corresponding author: victorhugomour@gmail.com
}

\begin{abstract}
Plant parasitic nematodes are major threats to Brazilian and world agriculture. Among them, Pratylenchus brachyurus and Meloidogyne incognita stand out as major pests for several crops, including corn, cotton, soybean among others, which can be components of integrated crop-livestock-forestry systems (ICLFs). In this context, information about the host status of eucalypts (Corymbia spp. and Eucalyptus spp.) to plant parasitic nematodes becomes more relevant in Brazil, due to the use of eucalypts in ICLFs. If tree components used on this system increase the population density of $P$. brachyurus and $M$. incognita, it is possible that these pathogens could damage shorter-cycle crops. Since information about the host status of eucalypts to plant parasitic nematodes is scarce, this study evaluated the host status of some eucalypt species to $P$. brachyurus and $M$. incognita. Two greenhouse trials were done to evaluate the reproduction of $P$. brachyurus and one to $M$. incognita, using some of the most cultivated species and hybrids of eucalypts in Brazil. The population growth of $P$. brachyurus increased on Corymbia citriodora, Eucalyptus grandis, Eucalyptus dunnii $\times$ Eucalyptus urophylla, and E. grandis $\times$ E. urophylla after $\sim 90$ days of inoculation. Conversely, despite $M$. incognita reproducing well in the control plants, no individuals were recovered from $C$. citriodora, $E$. urophylla and $E$. grandis $\times E$. urophylla, which were classified as resistant plants. Based on both obtained and available data, $M$. incognita poses no threat to eucalypt species today. However, $P$. brachyurus is suggested to be a threat to eucalypts.
\end{abstract}

Keywords: lesion nematode; root-knot nematode; integrated crop-livestock-forestry system.

\section{INTRODUCTION}

Plant parasitic nematodes are threats to Brazilian and world agriculture. There are over 4,100 species of phytonematodes and, collectively, they represent an important challenge for global food security (JONES et al., 2013). The economic impacts of these worms worldwide have been estimated at US\$ 80 billion per year (NICOL et al., 2011). However, there is a consensus in the nematological scientific community that the estimated losses do not reflect the true losses caused by plant parasitic nematodes, as several crops are not fully taken into consideration, such as several forestry species (LOPES; FERRAZ, 2016).

Eucalypts (Eucalyptus spp. and Corymbia spp.) are the most important forestry crops in Brazil. Several species are cultivated in this country, extending over 6.97 million hectares in 2019 (IBÁ, 2020). The main species of eucalypts are used to obtain wood, structural and furniture timber, charcoal, cellulose, essential oils, nectar, etc (MORA; GARCIA, 2000; PALUDZYSZYN FILHO; SANTOS, 2011).

Recently, information about the host status of eucalypts to plant parasitic nematodes became more relevant in Brazil, due to the use of eucalypts in the integrated crop-livestock-forestry system (ICLF). This system consists of the spatial-temporal combination of agriculture, livestock and forestry, through succession, rotation or intercropping (ASSIS et al., 2017; BALBINO et al., 2012). The ICLF offers an opportunity to obtain high productivity with minimal impact on the environment, in tropical agriculture, combining three activities in the same area (GIL et al., 2015). Corn (Zea mays L.), cotton (Gossypium hirsutum L.), and soybean (Glycine max [L.] Merrill) are the main crop components

Received: June 02, 2020. Accepted: Oct 29, 2021

Associate Editor: Silvia Galleti

Peer Review History: Double-blind Peer Review. 
and the brachiaria grasses are the main forage in ICLF. These crops are good hosts for important phytonematodes species, notably Meloidogyne incognita (CAMPOS; ROCHA, 1999; GALBIERI et al., 2009) and Pratylenchus brachyurus (INOMOTO et al., 2001). The brachiaria grasses are non-host of $M$. incognita, but moderate or good hosts of P. brachyurus (INOMOTO et al., 2007, INOMOTO; ASMUS, 2010).

Few reports are available regarding the association between $M$. incognita and eucalypts, although some attempts were made to evaluate the host status of some eucalypt species to nematode pests. CRUZ et al. (2003) reported the occurrence of Meloidogyne sp. in the soil and roots in orchards of Corymbia citriodora (syn. Eucalyptus citriodora), E. tereticornis, C. torelliana and E. urograndis. Eucalyptus grandis, E. urophylla and E. saligna were classified as non-host of Meloidogyne javanica and M. incognita (FERRAZ, L., 1980). Corymbia citriodora was classified as tolerant of M. javanica and intolerant to M. incognita based on greenhouse trials (FERRAZ, L.; LORDELLO, 1982; FERRAZ, L., 1982). Resistance and tolerance are different concepts and need to be further studied. Resistance in plant nematology is related to the ability of the plant to suppress nematode reproduction, while tolerance is the capability to withstand the damage caused by the plant parasitic nematodes (TRUDGILL, 1991; ROBERTS, 2002).

Regarding P. brachyurus infection of eucalypts, the first report of losses was done by LORDELLO (1967). On that occasion, the author reported highly infested seedlings of E. alba and E. saligna by P. brachyurus in an orchard located at Santa Maria da Serra (SP, Brazil). These plants showed a reduced necrotic root system with cortical displacement. The author also suggested the resistance of $C$. citriodora to P. brachyurus based on field observations, when symptomless C. citriodora seedlings were found growing besides decaying eucalypt plants. It is likely that the term "resistance" was misused and "tolerant" was more suited for the described by the author.

The most recent report concerning eucalypts and plant parasitic nematodes was done by BELLÉ et al. (2018), who showed the susceptibility of several species of eucalypts to P. brachyurus and P. zeae based on a single trial. Therefore, based on the current knowledge, eucalypts are susceptible to P. brachyurus and resistant to M. incognita. However, the response of plants to phytonematodes may change due to several facts, including the genetic variability of the host and the variability of the nematode population, as reported for many crops and forest species, such as melon (Cucumis melo $) \times$ M. javanica (DINIZ et al., 2016), guava (Psidium guajava) $\times$ P. brachyurus (PEREIRA et al., 2018), grape vine (Vitis vinifera) $\times$ P. brachyurus (SANTOS et al., 2019).

In this context, with the host status of several eucalypts classified based on single trial and a field observation from 1967 (BELLÉ et al., 2018; FERRAZ, L.; LORDELLO, 1982; LORDELLO, 1967), the present work determined the host status of three eucalypts species (C. citriodora, E. grandis and E. urophylla) and two hybrids (E. grandis $\times$ E. urophylla and E. dunnii $\times$ E. urophylla) to $P$. brachyurus and $M$. incognita. These species/hybrids are among the most economically relevant eucalypts in Brazil.

\section{MATERIAL AND METHODS}

At total of three greenhouse trials were done to evaluate the host status of eucalypts species to P. brachyurus (two trials) and to M. incognita (one trial).

\section{Plant material and inoculum source}

Eucalypt seedlings were obtained from seeds, which were donated by the Instituto de Pesquisas e Estudos Florestais (IPEF - Piracicaba, SP). The general information about the seeds and their source is summarized on Table 1. Eucalypt seedlings were obtained by direct sowing the seeds in a 500- $\mathrm{cm}^{3}$ plastic cup $(\mathrm{R}=4.3 \mathrm{~cm}, \mathrm{r}=3.0 \mathrm{~cm}, \mathrm{~h}=11.9 \mathrm{~cm})$ plastic pots containing $400 \mathrm{~cm}^{3}$ of autoclaved $\left(120^{\circ} \mathrm{C}, 2 \mathrm{~h}\right.$ ) sandy clay loam soil ( $62 \%$ of sand, $8 \%$ of silt, and $30 \%$ of clay). The seeds germinated 15 days after sowing. The seedlings were individually transferred to other $500-\mathrm{cm}^{3}$ plastic cups containing autoclaved sandy clay loam soil at 29 days after sowing. Finally, the seedlings were maintained in greenhouse under daily irrigation until inoculation.

Known susceptible hosts were included to evaluate the inoculum infectiveness and for comparison purposes. Soybean 'Pintado' (experiment 1), corn 'DKB 390' (experiment 1), cotton 'Delta Opal' (experiments 2 and 3) were included as positive controls (MACHADO et al., 2012) and slenderleaf rattlebox 'Common' (Crotalaria ochroleuca) (experiments 2 and 3) as negative controls (SOARES DA SILVA et al., 1989). The control plants were obtained by directly sowing in similar cups 46 days after eucalypt transplanting. 
Table 1. General information about the number, species, source of seeds, and orchards of the eucalypts used in the present work.

\begin{tabular}{ll}
\hline Eucalypts material & \multicolumn{1}{c}{ Orchard } \\
\hline Corymbia citriodora & SPA $^{*}$ Restinga (São Paulo state) \\
\hline Eucalyptus grandis & SPA $^{*}$ Anhembi (São Paulo state) \\
\hline E. urophylla & SPA $^{*}$ - Anhembi (São Paulo state) \\
\hline E. dunnii $\times$ E. urophylla & SPA $^{*}$ - Itatinga (São Paulo state) \\
\hline E. grandis $\times$ E. urophylla & SSO $^{* *}$ - Itirapina (São Paulo state) \\
\hline
\end{tabular}

"Seed production area (SPA) is an orchard containing a natural or a planted stand, maintained set aside from external pollen and periodically thinned in order to eliminate the weaker plants, and treated to stimulate seed production;

"* Seedling seed orchard (SSO) consists in an orchard of known genetic origin, established from seedlings from selected parents through natural or controlled pollination, with thinning based on individual and family performance, leaving only the best trees for seed production.

Source: Elaborated by the authors using data provided by Instituto de Pesquisa e Estudos Florestais (ESALQ/USP) and Faulkner (1975).

Inoculum of the plant parasitic nematodes was obtained from roots of previously infested host plants maintained in a greenhouse. For P. brachyurus, an aqueous suspension consisting of mixed life stages (J2, J3, J4, and females) was used as the inoculum, obtained from cotton roots using a modified Baermann method (HOOPER, 1986). The population used in this study (termed " $\mathrm{Pb} 23$ ") was originally isolated from samples collected from cotton fields, located in Sapezal (Mato Grosso, Brazil) and characterized by MACHADO et al. (2007). Inoculum of M. incognita consisted of an aqueous suspension consisting of eggs and $\mathrm{J} 2$ juveniles obtained from severed galled cotton roots. The roots were processed by blender and centrifugal flotation technique (COOLEN; D'HERDE, 1972). The M. incognita population was originally isolated from cotton samples from Campo Verde (Mato Grosso, Brazil) and identified by perineal-pattern morphology of mature females (EISENBACK, 1984). Inoculum from both nematodes was estimated by two counts of $0.5 \mathrm{~mL}$ by using a Peters' counting slide under light microscopy. The initial population used in all trials was 200 individuals.

\section{Inoculation procedures, experimental design and evaluation process}

The eucalypts were inoculated at 89 days after sown (DAS), i.e., 60 days after transplanting. Additionally, the cups containing cotton and slenderleaf rattlebox seedlings were inoculated. The seedlings were initially maintained in a shaded room for 2 days to avoid heat stress on the nematodes and then transferred to the greenhouse. The plants were maintained under daily irrigation until nematode reproduction was evaluated.

Therefore, the eucalypts and nematodes evaluated were the following: trial $1-C$. citriodora, E. grandis and E. urophylla were inoculated with P. brachyurus; trial 2 - C. citriodora, E. dunnii $\times$ E. urophylla, E. grandis, E. urophylla and E. grandis $\times$ E. urophylla were inoculated with P. brachyurus; trial $3-$ C. citriodora, E. urophylla and E. grandis $\times$ E. urophylla were inoculated with $M$. incognita. As the seeds presented lower germination during all trials, only these three eucalypts were used in the root-knot trial for presenting higher germination rates.

The evaluation was carried out at 95, 90 and 90 days after inoculation (DAI) for the trials 1, 2 and 3, respectively. The plants were removed from their pots and the roots were washed with tap water, dried on absorbent paper, cut in $1-\mathrm{cm}$ pieces, and weighed. Subsequently, roots were processed using the blender and centrifugal flotation technique (COOLEN; D'HERDE, 1972), using a centrifuge with four $125-\mathrm{cm}^{3}$ tubes $(10 \mathrm{~cm} \mathrm{high} \times 4 \mathrm{~cm}$ diameter) at $1,800 \mathrm{rpm}$ and $580 \mathrm{~g}$. Since nematodes other than P. brachyurus and $M$. incognita were almost undetectable, the nematode eggs recovered from roots were counted as either of $P$. brachyurus or $M$. incognita. It is noteworthy that soil samples $\left(200 \mathrm{~cm}^{3}\right)$ were used to recover the P. brachyurus from eucalypts and control plants in all trials according to JENKINS; TAYLOR (1968). However, few nematodes were recovered only from the control plants and no individuals were recovered from the eucalypt soil samples.

Thus, for each sample, the final population $(\mathrm{Pf})$, the reproduction factor $(\mathrm{R}=\mathrm{Pf} / \mathrm{Pi})$ and nematodes per gram of root (Nem/g) were estimated. A one-way analysis of variance (ANOVA) model, with Tukey's honestly significant difference (HSD) was used to compare the genotypes using the R Statistical software (R CORE TEAM, 2013). The data were submitted to the transformation $\log (\mathrm{x}+1)$ if they did not fulfill the requirements of Shapiro-Wilk normality test. 


\section{RESULTS}

Both P. brachyurus and $M$. incognita reproduced in the root of positive control plants, attesting the inoculum infectiveness. The $\mathrm{R}$ values obtained for $P$. brachyurus for corn (experiment 1 ), soybean (experiment 1 ) and cotton (experiment 2) were 77.7, 116.9 and 28.2, respectively. The R value for $M$. incognita obtained for cotton was 16.3 (experiment 3) (Table 2).

The population of P. brachyurus increased in roots of all eucalypt species evaluated. The R values did not statistically differ among the eucalypts in both trials, except for E. urophylla in experiment 2, which presented R value below 1. However, the eucalypts were statistically grouped apart from corn and soybean, presenting low $\mathrm{R}$ value when compared to the controls. The obtained $\mathrm{R}$ values ranged from 0.9 to 3.7 for E. urophylla (experiment 2) and E. urograndis (experiment 2), respectively. The highest values were obtained for E. urograndis (experiment 2), E. grandis (experiment 2) and E. urophylla (experiment 1), which were 3.7, 2.9 and 2.8, respectively.

Meloidogyne incognita reproduction was not observed in C. citriodora, E. urograndis and E. urophylla, despite the infectiveness of the inoculum. Additionally, no galls were visible on the root systems. Thus, these species can be considered as non-host for M. incognita.

Table 2. Reproduction factor (R) and number of nematodes per gram of fresh root $(\mathrm{Nem} / \mathrm{g})$ obtained for Pratylenchus brachyurus (experiments 1 and 2 ) and Meloidogyne incognita (experiment 3 ) for eucalypt species $\sim 90$ days after the inoculation.

\begin{tabular}{|c|c|c|c|c|c|c|}
\hline \multirow{3}{*}{$\begin{array}{l}\text { Species/hybrid of } \\
\text { eucalypts }\end{array}$} & \multicolumn{4}{|c|}{ Pratylenchus brachyurus } & \multirow{2}{*}{\multicolumn{2}{|c|}{$\begin{array}{c}\text { Meloidogyne incognita } \\
\text { Experiment } 3\end{array}$}} \\
\hline & \multicolumn{2}{|c|}{ Experiment 1} & \multicolumn{2}{|c|}{ Experiment 2} & & \\
\hline & $\mathbf{R}$ & $\mathrm{Nem} / \mathrm{g}$ & $\mathbf{R}$ & $\mathrm{Nem} / \mathrm{g}$ & $\mathbf{R}$ & $\mathrm{Nem} / \mathrm{g}$ \\
\hline Corymbia citriodora & $1.6 \mathrm{~b}$ & $177 \mathrm{~b}$ & $2.1 \mathrm{bc}$ & $34 \mathrm{bc}$ & $\mathrm{Ob}$ & $\mathrm{Ob}$ \\
\hline Eucalyptus urophylla & $2.8 \mathrm{~b}$ & $124 b$ & $0.9 \mathrm{c}$ & $14 \mathrm{c}$ & $\mathrm{Ob}$ & $\mathrm{Ob}$ \\
\hline E. grandis & $2.9 \mathrm{~b}$ & $217 b$ & $2.8 b c$ & $15 b c$ & - & - \\
\hline E. dunni $\times$ E. urophylla & - & - & $1.8 \mathrm{bc}$ & $39 \mathrm{bc}$ & - & - \\
\hline E. grandis $\times$ E. urophylla & - & - & $3.7 \mathrm{~b}$ & $47 \mathrm{~b}$ & $\mathrm{Ob}$ & $\mathrm{Ob}$ \\
\hline Slenderleaf rattlebox & - & - & $\mathrm{OC}$ & $\mathrm{Oc}$ & $\mathrm{Ob}$ & $\mathrm{Ob}$ \\
\hline Cotton ‘Delta Opal’1,2 & - & - & $28.2 \mathrm{a}$ & $1,100 \mathrm{a}$ & $16.3 \mathrm{a}$ & $2,127 a$ \\
\hline Maize ‘DKB 390’’ & $77.7 \mathrm{a}$ & $264 a$ & - & - & - & - \\
\hline Soybean 'Pintado'" & $116.9 a$ & $6,789 a$ & - & - & - & - \\
\hline
\end{tabular}

Each value is the average of six replicates. Averages followed by the same letter in column do not differ according to Tukey's honestly significant difference $(p=0.05)$. Values of $R$ and Nem/g were not transformed before ANOVA. 'Corn 'DKB 390', cotton 'Delta Opal' and soybean 'Pintado' were included in order to evaluate the infectiveness of $P$. brachyurus inoculum. ${ }^{2}$ Cotton 'Delta Opal' was included in order to evaluate the infectiveness of $M$. incognita inoculum. - Not tested in the trial.

Source: Elaborated by the authors.

\section{DISCUSSION}

The results are in agreement with that obtained by BELLÉ et al. (2018), who obtained $\mathrm{R}$ values $>1$ for $P$. brachyurus. However, the R values obtained by BELLÉ et al. (2018) were higher than the obtained in the present work, which can be attributed to the longer trial period ( 240 days versus $\sim 90$ days). Additionally, similar Nem/g values were obtained in the first trial of our research, which ranged from 124 to 217, compared to 173-354 obtained in their work. In our second trial, $\mathrm{Nem} / \mathrm{g}$ values were lower, even with similar $\mathrm{R}$ values (Table 1). This was probably due heavier roots from the eucalypt plants. However, our data disagree with the obtained by BELLÉ et al. (2018) regarding the soil populations, which were pronouncedly lower when compared to those obtained by BELLÉ et al. (2018). The authors obtained from 168 to 341 
P. brachyurus individuals per $100 \mathrm{~cm}^{3}$ of soil from the eucalypt and 526 individuals $/ 100 \mathrm{~cm}^{3}$ of soil from sorghum (positive control in their work). Despite the recovery of individuals from maize and soybean soil samples (78 and 117 per $100 \mathrm{~cm}^{3}$, respectively), no $P$. brachyurus were recovered from eucalypt soil (Data not shown).

Our data also disagrees from that obtained by LORDELLO (1967), who suggested that $C$. citriodora could be resistant to $P$. brachyurus. In our data, C. citriodora was considered susceptible, as $P$. brachyurus population increased in its roots.

FERRAZ, L.; LORDELLO (1982) performed inoculations of M. incognita and M. javanica in several forestry species, including C. citriodora, E. grandis, E. saligna and E. urophylla. The species E. grandis and E. urophylla showed high resistance to both $M$. javanica and $M$. incognita. The inoculation of $C$. citriodora seedlings with $M$. incognita caused severe galling in the roots, showing galls of different sizes on the main root. Occasionally, M. incognita females were found at 90 DAI. Our data partially disagrees with that obtained by FERRAZ, L.; LORDELLO (1982), as E. grandis and E. urophylla showed resistance since no nematodes were recovered.

FERRAZ, L. (1982) did several histopathological observations on C. citriodora roots colonized by M. incognita. That author reported the presence of typical feeding cells within the roots. However, in some cases, sedentary nematodes can induce feeding cells that provided enough food for the nematode to feed, but without any eggs being produced (FERRAZ, S. et al., 2010). This explanation can tie our results together.

The only available data with Meloidogyne sp. and E. urograndis is a single study that evaluated the host status of three genotypes to $M$. enterolobii. All genotypes were ranked as highly resistant or non-host to $M$. enterolobii, which is a limiting factor for guava production, a species from the same family as eucalypts (CARNEIRO et al., 2001).

\section{CONCLUSION}

Our data increases the knowledge about plant parasitic nematodes in eucalypts. Based on both obtained and available data, $M$. incognita poses no threat to the main eucalypt species currently cultivated in Brazil. However, the available studies point to $P$. brachyurus as the main plant parasitic nematode for eucalyptus. This could raise questions about the impact of eucalypt alleys in the annual crops grown along/near them or the planting of eucalypts in highly infested areas, which should be further studied.

\section{AUTHORS' CONTRIBUTIONS}

Conceptualization: Inomoto, M.M. Data curation: Souza, V.H.M. Formal analysis: Souza, V.H.M. Investigation: Inomoto, M.M.; Souza, V.H.M.

AVAILABILITY OF DATA AND MATERIAL

All data generated or analyzed during this study are included in this published article.

\section{FUNDING}

Conselho Nacional de Desenvolvimento Científico e Tecnológico

https://doi.org/10.13039/501100003593

Coordenação de Aperfeiçoamento de Pessoal de Nível Superior

https://doi.org/10.13039/501100002322

\section{CONFLICTS OF INTEREST}

All authors declare that they have no conflict of interest.

ETHICAL APPROVAL

Not applicable.

\section{ACKNOWLEDGEMENTS}

The authors would like to thank the Instituto de Pesquisas e Estudos Florestais (IPEF/ESALQ) for providing the eucalypt seeds. 


\section{REFERENCES}

ASSIS, P.C.R.; STONE, L.F.; SILVEIRA, A.L.R. da; OLIVEIRA, J. de M.; WRUCK, F.J.; MADARI, B.E. Biological soil properties in integrated crop-livestock-forest systems. Revista Brasileira de Ciência do Solo, Viçosa, v.41, e0160209, 2017. https://doi.org/10.1590/18 069657 rbcs20160209

BALBINO, L.C.; CORDEIRO, L.A.M.; OLIVEIRA, P. de; KLUTHCOUSKI, J.; GALERANI, P.R.; VILELA, L. Agricultura sustentável por meio da integração lavoura-pecuária-floresta (iLPF). Informações Agronômicas, Piracicaba, v.138, p.1-18, 2012. Available from: https:// ainfo.cnptia.embrapa.br/digital/bitstream/item/200295/1/Balbino-Agricultura-sustentavel.pdf. Access on: 8 Sept. 2020.

BELLÉ, C.; GROTH, M.Z.; KASPARY, T.E.; KHUN, P.R.; KULCZYNSKI, S.M. Reprodução de Pratylenchus spp. em espécies de eucalipto (Eucalyptus spp.). Nematropica, Auburn, v.48, p.45-49, 2018. Available from: https://journals.flvc.org/nematropica/article/view/106931. Access on: 1 Aug. 2019.

CAMPOS, H.D.; ROCHA, M.R. da. Reação de genótipos de milho (Zea mays L.) aos nematóides de galhas (Meloidogyne javanica e M. incognita). Pesquisa Agropecuária Tropical, Goiânia, v.29, n.2, p.13-17, 1999. Available from: https://www.revistas.ufg.br/pat/article/ view/2835. Access on: 1 Aug. 2019.

CARNEIRO, R.M.D.G., MOREIRA, W.A.; ALMEIDA, M.R.A.; GOMES, A.C.M.M. Primeiro registro de Meloidogyne mayaguensis em goiabeira no Brasil. Nematologia Brasileira, Piracicaba, v.25, n.2, p.223-228, 2001. Available from: https://ainfo.cnptia.embrapa.br/digital/ bitstream/item/183453/1/Nematologia-Brasileira-v.25-n.2-p.223-228-2001.pdf. Access on: 8 June 2019.

COOLEN, W.A.; D'HERDE, C.J. A method for the quantitative extraction of nematodes from plant tissues. In: Ghent. Belgium: State Agricultural Research Centre, 1972. 77p.

CRUZ, M.C.; OTOBONI, C.E. de M.; FERREIRA, R.V.; GOULART, S.L. Ocorrência de nematoides em genótipos de Eucalyptus e Pinus caribaea. Revista Científica Eletrônica Agronomia, Garça, v.2, 2003. Available from: http://faef.revista.inf.br/imagens_arquivos/ arquivos_destaque/ZuUOPBZi7GuAW2v_2013-4-26-9-53-18.pdf. Access on: 15 July 2019.

DINIZ, G.M.M.; CANDIDO, W. dos S.; SOARES, R.S.; SANTOS, L. da S.; MARÍN, M. V.; SOARES, P.L.M.; BRAZ, L.T. Reaction of melon genotypes to Meloidogyne incognita and Meloidogyne javanica. Pesquisa Agropecuária Tropical, Goiânia, v.46, n.1, p.111-115, 2016. https://doi.org/10.1590/1983-40632016v4639603

EISENBACK, J.D. Diagnostic characters useful in the identification of the four most common species of root-knot nematodes (Meloidogyne spp.). In: SASSER, J.N.; CARTER, C.C. (ed.). An advance treatise on Meloidogyne: Biology and Control. Raleigh: North Carolina State University Graphics, 1984. 95-112.

FAULKNER, R. Seed orchards. London: Forestry Commission, 1975. 180p.

FERRAZ, L.C.C.B. Nematoides parasitos de espécies de Eucalyptus, Pinus e outras essências florestais cultivadas no estado de São Paulo. 1980. Dissertation (doctoral dissertation in Agronomy) - Universidade de São Paulo, Piracicaba, 1980.

FERRAZ, L.C.C.B. Histopathological observations on the roots of Eucalyptus citriodora Hk. and Pinus caribaea var. caribaea Mor. infected by root-knot nematodes. Fitopatologia Brasileira, Brasília, v.7, n.1, p.91-96, 1982.

FERRAZ, L.C.C.B.; LORDELLO, L.G.E. Suscetibilidade e danos causados a espécies de Eucalyptus e Pinus por nematóides das galhas no estado de São Paulo. Brazilian Journal of Agriculture, Piracicaba, v.57, n.1-2, p.67-75, 1982. Available from: http://www.revistadeagricultura. org.br/index.php/revistadeagricultura/article/view/4165. Access on: 1 Aug 2019.

FERRAZ, S.; FREITAS, L.G. de; LOPES, E.A.; DIAS-ARIEIRA, C.R. Manejo sustentável de fitonematoides. Viçosa: Editora UFV, 2010.

GALBIERI, R. FUZATTO, M.G.; CIA, E.; LÜDERS, R.R.; MACHADO, A.C.Z.; BOLDT, A.F. Reação de cultivares de algodoeiro a Meloidogyne incognita em condições de campo e casa de vegetação no estado de Mato Grosso. Tropical Plant Pathology, Brasília, v.34, n.1, p.18-23, 2009. https://doi.org/10.1590/S1982-56762009000100003 
GIL, J.; SIEBOLD, M.; BERGER, T. Adoption and development of integrated crop-livestock-forestry systems in Mato Grosso, Brazil. Agriculture, Ecosystems \& Environment, Nanning, v.199, p.394-406, 2015. https://doi.org/10.1016/j.agee.2014.10.008

HOOPER, D.J. Extraction of free-living stages from soil. In: SOUTHEY, J.F. (ed.). Laboratory methods for work with plant and soil nematodes. London: Her Majesty's Stationery Office, 1986. p.5-30.

IBÁ - INDUSTRIA BRASILEIRA DE ÁRVORES. Relatório Anual 2020. São Paulo: IBÁ, 2020. Available from: https://files.cercomp.ufg. br/weby/up/986/o/relatorio-iba-2020.pdf. Access on: 29 Oct. 2021.

INOMOTO, M.M.; ASMUS, G.L. Host status of graminaceous cover crops for Pratylenchus brachyurus. Plant Disease, Saint Paul, v.94, n.8, p.1022-1025, 2010. https://doi.org/10.1094/PDIS-94-8-1022

INOMOTO, M.M.; GOULART, A.M.C.; MACHADO, A.C.Z.; MONTEIRO, A.R. Effect of population densities of Pratylenchus brachyurus on the growth of cotton plants. Fitopatologia Brasileira, Brasília, v.26, n.2, p.192-196, 2001. https://doi.org/10.1590/S0100-41582001000200013

INOMOTO, M.M.; MACHADO, A.C.Z.; ANTEDOMÊNICO, S.R. Reação de Brachiaria spp. e Panicum maximum a Pratylenchus brachyurus. Fitopatologia Brasileira, Brasília, v.32, n.4, p.341-344, 2007. https://doi.org/10.1590/S0100-41582007000400009

JENKINS, W.R.; TAYLOR, D.P. Plant Nematology. Soil Science, Philadelphia, v.106, n.4, p.326, 1968. https://doi. org/10.1097/00010694-196810000-00022

JONES, J.T. et al. Top 10 plant-parasitic nematodes in molecular plant pathology. Molecular Plant Pathology, Raleigh, v.14, n.9, p.946-961, 2013. https://doi.org/10.1111/mpp.12057

LOPES, E.A.; FERRAZ, S. Importância dos fitonematoides na agricultura. In: OLIVEIRA, C.M.G.; SANTOS, M.A. dos; CASTRO, L.H.S. (ed.). Diagnose de fitonematoides. Campinas: Millenium, 2016. p.1-14.

LORDELLO, L.G.E. Doença de eucaliptos causada por um nematoide. Brazilian Journal of Agriculture, Piracicaba, v.42, n.1, p.11-13, 1967. Available from: http://www.revistadeagricultura.inf.br/index.php/revistadeagricultura/article/view/1887. Access on: 12 Aug. 2019.

MACHADO, A.C.Z.; FERRAZ, L.C.C.B.; INOMOTO, M.M. Pathogenicity of Pratylenchus brachyurus. The Journal of Cotton Science, Memphis, v.16, n.4, p.268-271, 2012. Available from: https://www.cabdirect.org/cabdirect/abstract/20133012926. Access on: 12 Aug. 2019.

MACHADO, A.C.Z.; FERRAZ, L.C.C.B.; OLIVEIRA, C.M.G. Development of a species-specific reverse primer for the molecular diagnostic of Pratylenchus brachyurus. Nematropica, v.37, n.2, p.249-257, 2007. Available from: https://journals.flvc.org/nematropica/ article/view/64430. Access on: 13 Aug. 2019.

MORA, A.L.; GARCIA, C.H. A cultura do Eucalipto no Brasil. São Paulo: Sociedade Brasileira de Silvicultura, 2000. Available from: http:// atividaderural.com.br/artigos/50ec5305728a6.pdf. Access on: 1 June 2019.

NICOL, J.M.; TURNER, S.J.; COYNE, D.L.; DEN NIJS, L.; HOCKLAND, S.; MAAFI, Z.T. Current nematode threats to world agriculture. In: JONES, J.T.; GHEYSEN, G.; FENOLL, C. (ed.). Genomics and Molecular Genetics of Plant-Nematode Interactions. Heidelberg: Springer, 2011. p.21-44.

PALUDZYSZYN FILHO, E.; SANTOS, P.E.T. dos. Programa de melhoramento genético de eucalipto da Embrapa Florestas: resultados e perspectivas (Documentos 214). Colombo: Embrapa Florestas, 2011. Available from: https://ainfo.cnptia.embrapa.br/digital/bitstream/ item/47676/1/Doc214.pdf. Access on: 23 June 2019.

PEREIRA, K.C. SOARES, P.L.M.; SANTOS, J.M. dos; FELISBERTO, P.A. de C. Reação de cultivares de goiabeiras à Pratylenchus brachyurus. Summa Phytopathologica, Botucatu, v.44, n.4, p.386-390, 2018. https://doi.org/10.1590/0100-5405/178517

R CORE TEAM. R: A Language and Environment for Statistical Computing. Vienna: R Foundation for Statistical Computing, 2013. Available from: http://www.R-project.org/. Access on: 19 July 2019.

ROBERTS, P.A. Concepts and consequences of resistance. In: STARR, J.L.; COOK, R.; BRIDGE, J. (ed.). Plant resistance to parasitic nematodes. Wallingford: CABI, 2002. chap.2, p.23-41. 
SANTOS, P.R. dos; VIANA, A.P.; GOMES, V.M.; PREISIGKE, S. da C.; ALMEIDA, O.F. de; SANTOS, E.A.; RODRIGUES, D.L.; RODRIGUES, R.; WALKER, M.A. Resistance to Pratylenchus brachyurus in Vitis species population through multivariate approaches and mixed models. Scientia Agricola, Piracicaba, v.76, n.5, p.424-433, 2019. https://doi.org/10.1590/1678-992x-2017-0387

SOARES DA SILVA, G.; FERRAZ, S.; SANTOS, J.M. dos. Resistência de espécies de Crotalaria a Pratylenchus brachyurus e P. zeae. Nematologia Brasileira, Piracicaba, v.13, n.1, p.81-86, 1989.

TRUDGILL, D.L. Resistance to and Tolerance of Plant Parasitic Nematodes in Plants. Annual Review of Phytopathology, Santa Cruz, v.29, p.167-193, 1991. https://doi.org/10.1146/annurev.py.29.090191.001123 